\title{
Synet
}

\section{Et ungdomsdigt af Grundtvig}

Da Grundtvig i maj 1808 havde truffet den unge historiker Christian Molbech og foræret ham et eksemplar af sin nysudkomne første bog - "Maskeradeballet i Dannemark 1808" med undertitlen "Et Syn" - fremkaldte denne gave et meget personligt brev fra Molbech, hvortil vi kun kender et udkast, der er trykt $\mathrm{i}$ brevvekslingen mellem de to mænd, udgivet 1888 af Ludvig Schrøder. Grundtvig besvarede dette brev med en lige så oprigtig selvkarakteristisk og vedlagde, som han skriver, "et par Vers, Fragmenter af mit indre Livs Historie, der som tro Præg af min Individualitet have ligesaameget og ligesaalidet Værd som den. Hvorfor jeg valgte netop disse, vil Indholden strax sige Dem." De er alle trykt i tillægget til brevvekslingen, men har ikke siden været genoptrykt.

Det første af disse seks digte, som er dateret 14. maj 1804, er et fødselsdagsdigt til Grundtvigs eneste søster Ulrike Eleonore, som døde halvandet år senere. Derpå følger et nytårsdigt til hans ældste broder Otto fra 1805, og derefter tre digte til Constance Leth, hvem han kalder Laura, et "med en Fiol", et "med en Rose" og et med overskriften "Afskeden". Det 6. og sidste digt, som genoptrykkes her, skildrer en vision af hans søster, der opfordrer ham til, i bogstavelig forstand, at kaste sin kærlighed over på den nordiske mytologi.

Digtet optrykkes her efter manuskriptet i Ny kgl. Samling 3091 $4^{o}$. Førstetrykket i "Christian Molbech og Nikolai Fredrik Severin Grundtvig. En Brevvexling" afviger ikke fra originalmanuskriptet undtagen ved et tilføjet komma eller punktum hist og her. - Ordet Ifing, i digtets sidste linie, er navnet på grænsefloden mellem aser og jætter. 


\section{Synet}

Ene jeg i Midnatstimen sad,

Mellem gamle Nordens Skygger Ene,

Stirrende paa Eddas dunkle Kvad

Og paa Brynhilds røde Bautastene

Stjernelysets matte Skin

Svandt som slukt af Stormens Aande

$\mathrm{Og}$ for mig var Stormens Hvin

Genlyd af Brynhildes Vaande

Underlig lænked det Eviges Haand

Tidernes glatte, elektriske Ringe

Fjerne, dog Eet med iboende Aand,

Rörte, i samlede Toner de klinge

Jeg tyed til Heltenes glimrende Old

At glemme mig selv og mit blødende Hjerte

Men Heltenes Fryd jeg beskuede kold,

Og fölte mig knuset af Heltenes Smerte

Jeg tændtes af Brynhilds fortærende Lue

Der sögte sin Svale i rygende Blod

Men voxte og slog imod Himmelens Bue

Da Fængslet oplöstes i gloende Flod.

Trindt mig var Stille

Selv var jeg stille

Omknuget af Furiers Belte

Min Kraft var vegen

Og ej min egen

Jeg var i fjendtlige Magters Vold.

De havde grebet

Brudt Væsnets Ror

Af Bölgen drevet

Mod Fjeld jeg foer.

Ufölsom skued

Jeg egen Gang 
Det Fjeld, som trued

Med Undergang

De Sener spændtes til bitter Smil

Jeg haanlig spurgte: kan Smertens Pil

Hvis Gift sig trængte til Hjertets Rod

Udfare, lukke den dybe Vunde,

Udsuge Giften, thi da först kunde

Den atter raadne det ferske Blod

Ja, kan vel Den

Som er Intet, end

Tilintetgöres?

Han kan - Saa löde

I Nattens Øde

Bekendte Toner

Som gennembæved

Mit Væesens Alt.

Sig Øjet hæved,

En hvid Gestalt

Imod mig svæved

Med lette Fjed

Sorg var i Öjet, men salig Glæde

Dog straaled frem gennem Sorgens Klæde

Med kærlig Alvor Den mig beskued

Og löfted mod mig sin blege Haand

Min Sjel var styrket, ej mer jeg grued

Det var min Söster, den Huldes Aand

En Taare svaled mit hede Öje,

Min Kraft opvaagned af lange Blund,

Min Haand sig vilde til Haanden föje

Som sidst jeg trykked i Dödens Stund.

Jeg fatted Luften, jeg foer tilbage

Og Læben aabnede sig til Klage,

Da talte Aanden med dæmpet Röst.

Stöv har endt

Vandringen i Jordens Sköd.

Kærlighed, i Stövet tændt,

Luttres til en hellig Glöd 
Jeg saa Dig lide Gaa Sorgens Vej

Jeg saa Dig stride

Og frygted ej

Jeg saa Dig blegne

Ved Kampens Syn

Jeg saa Dig segne

For Smertens Lyn

Jeg skælved. Jeg bad

Bönhörtes, og glad

Jeg daled ned

At skænke Dig Fred.

Jeg

Saa kom Du at vinke mig hist til det Höje, Saa kom Du at skænke mig Gravenes Ro, Thi Död er mit Liv. For mit jordiske Öje Fortvivlelsens giftige Urter kun gro.

Aanden

Du spotter den Evige - Ti!

Jeg

Saa spotted og Jorden som Ploven oprev

Med hvæssede Staal for de nyskaarne Render, Ej selv den tilbage i Furen sig drev, Men bied paa Harvens de söndrende Tænder

Aanden

Af Jord blev Manden og Du er Jord, Men Jord, belivet af Herrens Aande

Det Döde viger for Livets Spor

Men Livet voxer i Stridens Vaande

Jeg

De lette Draaber hule haarden Steen

Som Staalet selv at trodse endog voved 
De tunge Draaber falde paa mit Hoved Og huled Marven ud af mine Been

Aanden

Udhultes Stenen, hvis den kunde Sig svinge over Draabens Hjem?

Jeg

Men kunde den sig did opsvinge Naar Storme knækked spæde Vinge Som voxed af dens Indre frem?

\section{Aanden}

Ej for i Ordspil Dig af öve Ej for mit Vid og dit at pröve Jeg steg fra Glædens Bolig ned. Jag Nattens Skygger fra dit Öje, Besku det Evige, det Höje!

Og Du skal nyde Sjelefred.

Jeg

$\mathrm{Ja}$, var jeg Aand som $\mathrm{Du}$, og kunde

Det gaadefulde Liv udgrunde

Beskue ham som er og var, Men Vi i Spejlet kun beskue $\mathrm{Og}$ naar det brydes, maa Vi grue.

Aanden

Og hvem kan Spejlet sönderbryde Hvor Rummet, Tiden sammenflyde Til een afbildende Gestalt

Jeg

Ja, Du er viis, jeg er en Daare Hvad jeg kan sige, veed Du Alt Men see den salte, tunge Taare Som furer, huler blege Kind! Den vælter ud fra Hjertets Kilde, 
Og Intet kan min Kval formilde Saalænge jeg er her paa Jord

Jeg saa en Kvinde - Solens Fader Omsvöbte Hende med sin Glands

I Hende Blomsters Myriader

Sig havde flettet til en Krands

Af Andagt luede mit Hjerte,

Af andagtsfulde Kærlighed

Ej mer paa Jorden jeg begærte

End evig taus at knæle ned.

Ej maa jeg knæle - Spejlet brödes, Og Billedet kan ej genfödes

Aanden

Naar Solen staar paa Himlens Blaa

Og spejler sig i brede Strande

Mon Du da ej dens Billed saa

Om fyldte bleve Bækkens Vande?

Jeg
Jeg saa det - men -

Aanden

Og dog Du tror at Solens Fader Imellem Draabers Myriader

Kun i den ene spejled sig!

\footnotetext{
Jeg

Kun spejled sig i den for mig

Jeg stirrer fast paa hver en Kilde

Omfatte jeg saa gerne vilde

Hvert Straalebilled som jeg seer;

Men Solen frem paa Himlen iler

Paa mörke Bölge Öjet hviler,

Og Billedet er ikke meer.
} 
Aanden

Fordi Du Synet selv forvirrer

Fordi Du kun ufölsom stirrer.

Jeg

O! kan Man have fölt og föle?

Og steeg vel een harmonisk Lyd

Fra Harpens eengang brustne Stræng

Aanden

Du stirred med forborgen Fryd

Paa gamle Nord saa fast og længe

Hold op at stirre, vov at se

Den Stores Billed varigt stande

I Ifings aldrig frosne Vande! 